\title{
Molecular investigations on the Rajanpuri strain of Beetal goat breed of Pakistan by complete mtDNA displacement region
} and microsatellite markers

\author{
A. Wajid ${ }^{\gamma}$ T. Hussain ${ }^{\gamma}$, F. M. M. T. Marikar*, M. M Musthafa, K. Abbas, \\ A. Ali and M. E. Babar
}

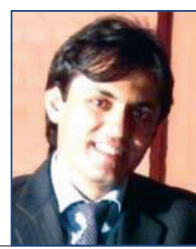

\section{Abstract}

The mitochondrial DNA sequences of DNA-D loops (mtDNA) from 105 individuals (11 Beetal goat Rajanpuri strains and 94 sequences extracted from GenBank) from 19 geographically and phenotypically defined domestic goat breeds in Pakistan were analysed in this experiment. In this study, we examined variability and molecular phylogeny of breeds. A total of 81 haplotypes were observed in 105 individuals, with a haplotype diversity of $0.984 \pm 0.006$ and nucleotide diversity of $0.03953 \pm 0.00843$. Phylogenetic analysis based on the mtDNA hyper variable segment (HVI) of the control region (481 bp), showed four mtDNA haplogroups (A, B1, C, and D) identified in Pakistani domestic goats, in which haplogroup A (84.11\%) was dominant and widely distributed among all investigated breeds. The study revealed that all Rajanpuri strain haplotypes belonged to haplogroup A. The Rajanpuri is a rare local strain of Beetal goat breed located in western Punjab province of Pakistan. The results of genetic diversity based on 11 microsatellite loci revealed allelic diversity (3.6363) and high genetic diversity (0.8342) in the examined Rajanpuri goat breeds. The analysis for signature bottleneck events, using three models, revealed significant deviation of Rajanpuri goats from mutation drift equilibrium. The qualitative test of mode shift analysis also supported the results obtained under three models, indicating the presence of a recent genetic bottleneck in the Rajanpuri strain. This study provides the first information on the mtDNA architecture, genetic diversity and bottleneck analysis, which will be useful in the conservation and management of the highly valued Rajanpuri goat.

Key words: $m t D N A$ D-loop; phylogenetic analysis; microsatellite markers; bottleneck analysis; Rajanpuri goat; Pakistan

Dr Abdul WAJID $\gamma$, PhD, Tanveer HUSSAIN $\gamma$, PhD, Full Professor, Kamran ABBAS, PhD, Akhtar ALI, $\mathrm{PhD}$, Masroor Ellahi BABAR, PhD, Full Professor, Department of Molecular Biology, Virtual University of Pakistan, Lahore, Pakistan; Faiz M. M. T. MARIKAR*, PhD, (Corresponding author, e-mail: faiz@kdu. ac.lk), General Sir John Kotelawala Defense University, Ratmalana, Sri Lanka; Muneeb M. MUSTHAFA, Faculty of Technology, South Eastern University, Oluvil, Sri Lanka

$\gamma$ Authors contributed equally as first author 


\section{Introduction}

The domestic goat (Capra hircus) is reared worldwide, especially in China, India and other developing countries (Pringle, 1998). Domestic goats are multipurpose animals that offer a variety of useful products in the form of meat, milk and textile fibre. Pakistan is rich in animal genetic resources, with 30 goat and 34 native sheep breeds (Hussain et al., 2013; Babar et al., 2014). Goats serve as an important source of meat, milk, fibre and pelts, and have commercial value in Pakistan (Babar et al., 2014). In recent years, molecular and population genetic studies, focusing on microsatellite markers and mitochondrial DNA control region and the cytochrome $b$ gene, have been performed on Pakistan's small ruminants (Sultana et al., 2003; Ahmed et al., 2014).

Domestic goat breeds in Pakistan are a very important source of information. In several studies, Pakistan has been determined to be a Fertile Crescent, from which the patterns of human migration and trade spread quicklz (Sultana et al., 2003). The varying geography of the region is an important factor for goat genetic diversity. Central Asian countries, such as Iran, Pakistan, China, and India, have been centres of human migration, tourism, and commerce for thousands of years. Among all livestock, goats may be the most transported (Luikat et al., 2001), and Pakistan may also be a distribution centre for mtDNA haplotypes. In particular, the Beetal goat breed is an important milk variety found throughout the Asian continent. From the geographic standpoint, this species is found across large parts of India and Pakistan and is widely adapted to a range of agricultural and ecological conditions. During the Muslim League split, people who guarded these races immigrated to Pakistan and were settled into Lahore, Khandwa, Okara and Sahiwal. The first tribe is Aspasioi and the second tribe is
Nagri, found in Sahiwal is pure red in colour. The third tribe is Makhi Cheena, found in Bahawalpur, Bahawalnager, Chishtian and Hasilpur, and very often has beautiful and attractive colours: black and brown, white makhis. The fourth tribe consists of Rajanpuri goats, found in Rajanpur, Dera Ghazi Khan, Rahim Yar Khan and Liaqatpur in Punjab, Pakistan and are pure white in colour, which is more difficult to maintain in other areas. Beetal is one of the largest Indian breeds and this breed is found in Punjab along the Indo-Pakistani border. Thus, the Beetal variety has adapted to change its colour and body structure while living in different regions. In the Manddi Bahauddin, Jehlum, Gujrat and Kharyan regions, this variety has a luxurious brown coat with a light brown spot, while in the north it has long hair. In Sindh, they are called Kamori.

Recently, several phylogeographical studies have been conducted to better understand the goat (Luikat et al., 2001; Chen et al., 2005; Naderi et al., 2007). Mitochondrial DNA (mtDNA) plays an important role in the genetic evolution and phylogenetic studies of goats (Han et al., 2010). One of the most important parts of the mitochondrial genome is the mtDNA (HVRl) high hypervariable region 1, with wide research on development systems and evolutionary change concentrated in this area (Luikat et al., 2001). To date, six different phylogenetic groups of goats have been identified around the world, with mtDNA haplogroups such as A, B, C, D, F and G, of which, haplogroup $A$ is the most important. Haplogroup B consists of B1 and B2, where B1 generally exists in South Asia and East Asia, including Pakistan, China, India, Laos and Malaysia, while B2 is found mainly in China and Mongolia. Haplogroup $C$ is found in Pakistan, China, France, Mongolia, Switzerland, Spain, and Slovenia, with 
a lower incidence in Asia, Portugal and India (Naderi et al., 2007). Although Haplogroup D is found in Pakistan, India, China and Austria, it is found in many other countries though mainly at a low frequency. Haplogroup F appears only on the island of Sicily, Italy. Haplogroup $\mathrm{G}$ is also present in low frequency, especially in Turkey, Egypt, Saudi Arabia and Iran (Meadow, 1996).

An analysis of the genetic diversity within and between tribes provides valuable information for understanding population structure and the relationships necessary for indigenous breed protection (Glowatzki-Mullis et al., 2009). Molecular markers as microsatellite markers, mitochondrial DNA and multi-state of a single nucleotide (SNP), have been developed around the world (Li et al., 2002; Canon et al., 2006) for many years. Microsatellites are used more often than other markers because they are randomly distributed in the genome, with high polymorphisms, high mutation rates, codominance and neutrality testing in nature, while micro markers are used for diversity and structure selection studies (Wajid et al., 2013). There are several national goat resources in Pakistan. However, little research has been done on the genetic diversity of goat breeds at a small geographic scale. In this regard, this is the first study to examine the genetic diversity of the local Rajanpuri strain of the Beetal goat breed.

\section{Material and Methods}

\section{Sampling and nucleic acid extraction}

$5 \mathrm{~mL}$ of whole blood was collected from 32 unrelated Rajanpuri goats from the one farmhouse. DNA was extracted from whole blood according to the method described in Hussain et al. (2013), using Nanodrop (Thermo Scientific, USA) quantitative gene groups DNA and diluted to a final concentration of $50 \mathrm{ng} /$ $\mu \mathrm{L}$ and stored at $-20^{\circ} \mathrm{C}$ until analysis.

\section{DNA amplification and sequencing}

The entire mtDNA D-loop region was examined with two set of primers mtDNA-F1-ATGCGTAGTAGTACAGTAGC, mtDNA-R1-ATTTGTGGCTGCTGATAGTG. A fragment of $566 \mathrm{bp}$ and mtDNA-F2-TGGATGCTGATGATGTGGG, mtDNA-R2-TGGATGTGAAGG CGTCGTTGC was used for the amplification of 640bp. Polymerase Chain Reaction (PCR) was carried out in final volume of $25 \mu \mathrm{L}$, containing $50 \mathrm{ng} / \mu \mathrm{L}$ genomic DNA, $10 \mathrm{pMol}$ of each primer, $100 \mathrm{uM}$ dNTPs mix, 1X $\left(\mathrm{NH}_{4}\right)_{2} \mathrm{SO}_{4}$ buffer, $2.5 \mathrm{mM} \mathrm{MgCl}_{2}$ and $1 \mathrm{U}$ Taq DNA polymerase (Fermentas). The PCR reaction conditions include $95^{\circ} \mathrm{C}: 5 \mathrm{~min}$ in BioRad thermocycler followed by 35 cycles: 95 ${ }^{\circ} \mathrm{C}: 30 \mathrm{~s}, 60-50{ }^{\circ} \mathrm{C}: 30 \mathrm{~s}$ (Touch Down with 1.0 increment/cycle), $72{ }^{\circ} \mathrm{C}: 45 \mathrm{~s}$, and the final extension was at $72{ }^{\circ} \mathrm{C}$ for $10 \mathrm{~min}$ utes. The PCR products were confirmed on $1.2 \%$ agarose gel electrophoresis and bands were excised and purified using alcoholic precipitation. The sequencing was performed using the BigDye Terminator Cycle Sequencing Reaction Kit through the ABI PRISM 3130 xL automated sequencer (Applied Biosystem, Foster City, CA, USA).

\section{Sequencing, mitochondrial and phylogenetic analyses}

Sequences were passed through BioEdit v7.0.9.1 (Hall, 1999). Haplotype and nucleotide diversity were estimated using DNaSP v4.1 software (Librado and Rozas, 2009). Using the maximum parsimony (MP) method, we chose the tree having the highest likelihood value as our best from the network 4.5.1.2 (Bandelt et al., 1999) and MEGA 6 (Tamura et al., 2013). The tree was constructed from 481 bp using a high variation section fragment with 11 of 94 sequences specific to Rajanpuri goats. Sequences of 19 species of Pakistani goats were obtained from GenBank. The phylogenetic analysis further comprised a reference to 
a previous sequence of six single-groups, A, B, C, D, E and G, according to Naderi et al. (2007). The reference sequence was used in the phylogenetic analysis to determine the identity of the haplogroup in the current isolate. Genetic variation data includes demographic historical information. MtDNA of mismatch distribution (for comparison) is usually used to investigate demographic events (Rogers and Harpending, 1992). Two standards have been developed: non-multimodal distribution rules must have a constant population size, and growing populations have a uniform single peak distribution. Another important model is the $\mathrm{Fu}$ F-Statistic (Fu, 1997), which providing sensitive testing for population growth and expansion. The test is based on the probability that some alleles are greater than or equal to the number of alleles observed in a static population sample.

In the system phylogeny analysis, JModeltest 2.1.7 determined the appropriate DNA model analysis. In this analysis, the best model of $\mathrm{HKY}+1$ was found for Neighbour connection parameters using the appropriate Bayesian information criteria. The original tree was analysed by BioNJ using PhyML 3.1. Bayesian analysis was implemented using MrBayes 3.2. Finally, a random starting shirt was used for analysis, yielding 10,000,000 generations for all species sequence data (100\% of bootstrap support. The pairwise difference matrix was performed using NETWORK 4.5.1.2 (Bandelt et al., 1999). Furthermore, wild and domestic breeds were analysed. Fu and Li's $\mathrm{D}^{*}$ compared the number of derived singleton mutations and the total number of derived nucleotide variants, while $\mathrm{Fu}$ and $\mathrm{Li}^{\prime} \mathrm{s} \mathrm{F}^{*}$ compared the number of derived singleton mutations and the mean pairwise difference between sequences.

\section{Submission of sequences to NCBI}

All 11 complete mitochondrial D-loop DNA sequences were submitted to
GenBank with the accession numbers: KP776451, KP776452, KP776453, KP776454, KP776455, KP776456, KP776457, KP776458, KP776459, KP776460, KP776461.

\section{Microsatellite genotyping and amplification}

The Food and Agriculture Organization (FAO) recommends 11 fluorescently labelled microsatellite markers (ETH152, MAF70, MAF33, MM12, BM1314, BM1818, ILSTS011, INRA32, OarAE101, OarFCB48 and OarVH72). The International Society for Animal Genetics (ISAG) recommends estimation of the count of various parameters of genetic diversity. Direct primers were labelled with only one of the FAM, PET, VIC and NED dyes supplied by Applied Biosystems, USA. The $25 \mu \mathrm{L}$ best final inoculation volume of microsatellite markers was used. A reaction mixture of amplified substantially similar formulations and conditions was used. PCR products were separated through $1.2 \%$ agarose gel electrophoresis. After purification, the PCR products were sequenced and fragments analysed in both directions by using an automated sequencer (ABI Prism 3730 XL DNA Analyzer) in BOWEI (PR of China, Nanjing).

\section{Data analysis}

Microsatellite genotypes were observed using GeneMapper (TM) software version 3.7 (Applied Biosystem analysis allele). In order to confirm the correct genotype, scoring and visual inspection were performed prior to analysis. Genotype data of 11 microsatellite markers amplified in Rajanpuri goats was analysed to calculate the observed $(n a)$ and effective number (ne) of alleles, allele frequency, observed $\left(\mathrm{H}_{\mathrm{obs}}\right)$ and expected $\left(\mathrm{H}_{\text {exp }}\right)$ heterozygosity by using POPGENE v1.31 (Yeh and Yong, 2015). GENEPOP v4.0 was used for the calculation of inbreeding coefficient $\left(\mathrm{F}_{\text {IS }}\right)$ values, while POWERSTAT v1.2.1 
was used to measure the polymorphic information content (PIC) by utilizing allele frequencies to determine the usefulness of markers. To ensure the reduction in effective population size, the bottleneck program (Piry et al., 1999) was used by utilizing three tests: sign, standardization differences and Wilcoxon sign rank test. These tests were used under the statement of mutation drift equilibrium in the infinite-alleles model (IAM), two phase of mutation (TPM), and stepwise mutation model (SMM). The mode-shift analysis was determined by utilizing the allele frequency distribution using bottleneck software v1.2.02.

\section{Results}

\section{Mitochondrial D-loop analysis and sequences polymorphism}

The mtDNA HVR-1 contained a high level of polymorphism with 273 variable sites in 481 bp segments in 105 Pakistani goat sequences (11 new sequences from the currently studied Rajanpuri goat, while 94 sequences were retrieved from GenBank representing 19 Pakistani goat breeds). We observed a total of 81 haplotypes. The average number of nucleotide differences (K) observed among the investigated goat breeds was 19.01419 (Table 1).

\section{Phylogenetic and haplogroup analysis}

A maximum likelihood tree was constructed using 105 Pakistani goat sequences and 50 reference sequences from neighbouring countries (China and India) representing all six haplogroups (A, B, C, D, E, and G). The results revealed that all investigated Pakistani goat breeds belonged to four haplogroups (A, B, C, and D), and all four haplotypes identified in the Rajanpuri goat belonged to haplogroup A. Haplogroup A was dominant with 88 individuals, 10 individuals belonged

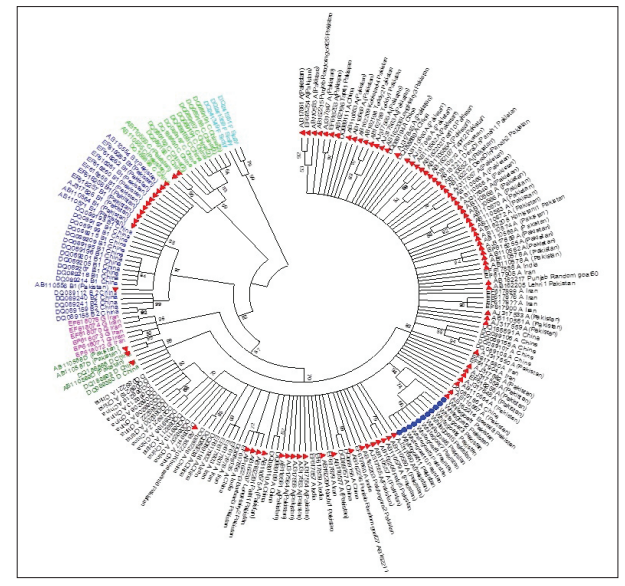

Figure 1. Neighbour-Joining (NJ) tree of domestic goat based on Mitochondrial D-Loop HVRI region (481 bp). Red triangles represent Pakistani goat breeds distributed in various taxa. Blue circles indicate the Rajanpuri goats investigated in this study. Clockwise, black lettering represents Group A, blue indicates Group B (B1 \& B2), lime indicates Group C, green represents Group D, aqua represents Group F and fuchsia represents Group G

to the B1 haplogroup, two individuals belonged to $C$ haplogroup and three individuals belonged to $\mathrm{D}$ haplogroup. No individuals were observed belonging to haplogroup F or G. Chen et al. (2005) divided haplogroup B into two subclades B1 and B2, however all Pakistani haplotypes belonged to the B1 category. The maximum likelihood tree of 105 PAK mtDNA D-loop region sequences, together with 50 reference sequences belonging to all six haplogroups (Naderi et al., 2007), is presented in Figure 1. The tree exhibited clear patterns of the six genetically defined haplogroups, and all Pakistani goat sequences clustered into the haplogroups A, B1, C and D, with Rajanpuri goat sequences clustering only into haplogroup A. Haplogroup A was the predominant haplogroup in all breeds of goat studied. Haplogroup B1 was found only in Beetal, Teddy, Nachi and long hairy goat breeds. Haplogroup $C$ was shared by two different goat 


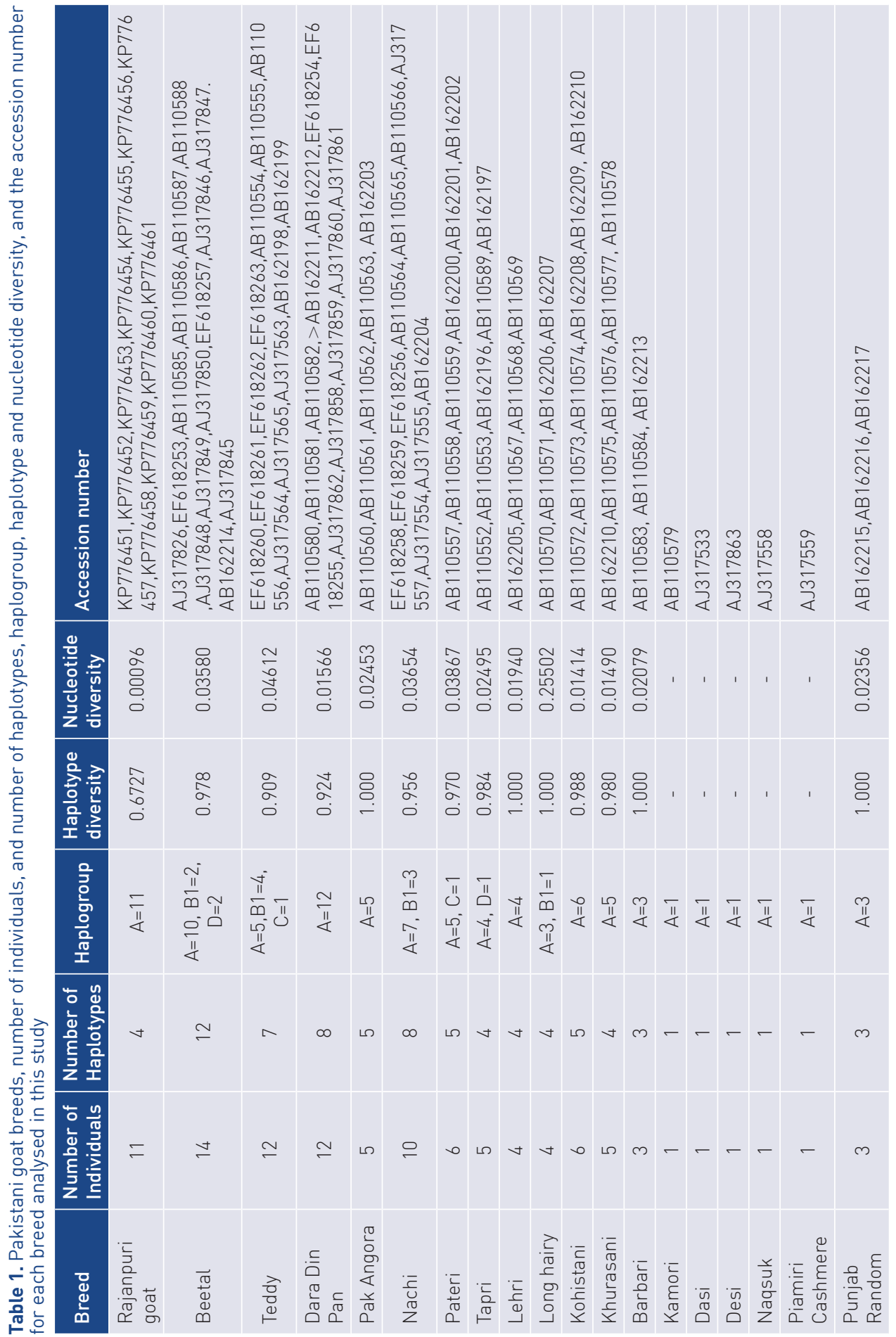


breeds (Teddy and Pateri) within a similar haplotype, while Haplogroup D was observed only in two individuals of Beetal and one individual of the Tapri breed.

The Median-Joining network analysis results further supported the phylogenetic relationships among Pakistani domestic goats, revealing that breeds from different geographical regions were intermingled. The network showed that the breeds had a dispersed distribution. Figure 2 shows that

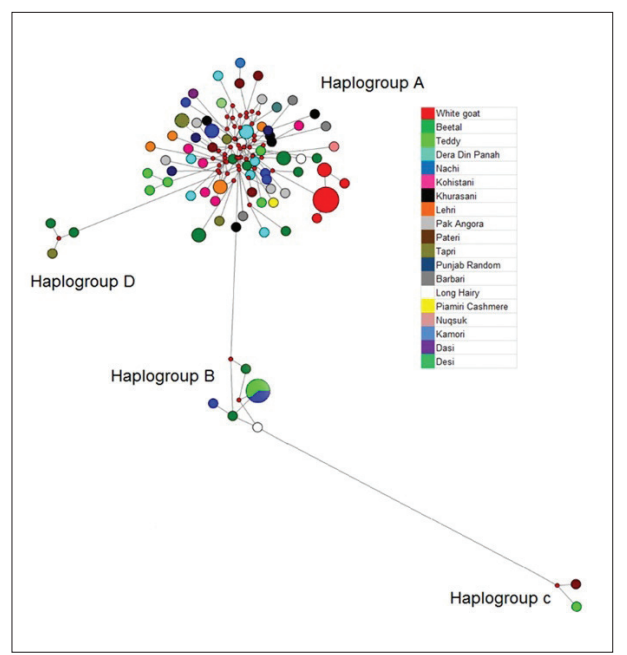

Figure 2. Median-Joining network of 81 haplotypes of Pakistani goats. Circle size is proportional to haplotype frequency haplogroup A is highly diversified and broadly distributed across all breeds in various geographical regions. It was noted that the haplotype of goats from diverse geographical regions did not cluster together and were instead dispersed throughout the network. The network analysis showed that there is no relationship between the geographical regions of origin and relationships among breeds.

\section{Genetic diversity}

The estimated genetic diversity among breeds based on complete mtDNA control region sequences is presented in Table 1. The Rajanpuri goat has low genetic diversity (0.6727), while the Kohistani, Pateri Pak Angora, Tapri, Lehri, Long Hairy Barbari, Punjab random and Piamiri cashmere, Naqsuk, Dasi, Desi, Kamori breeds have high genetic diversity (1.0000). Teddy goat displayed the highest nucleotide diversity value (0.04612), while the newly characterized Rajanpuri goats displayed low nucleotide diversity (0.00096). The results of the genetic diversity analysis of four haplogroups are presented in Table 2. Haplogroup A had the highest nucleotide diversity $0.02835 \pm 0.00987$. Haplogroup D had highest genetic diversity $1.000 \pm 0.272$, although haplogroup A exhibited high genetic diversity $(0.985 \pm 0.007)$.

Table 2. Genetic diversity in mtDNA haplogroups in Pakistani domestic goat breeds

\begin{tabular}{|l|c|c|c|c|c|c|c|}
\hline Haplogroups & $\begin{array}{c}\text { Num- } \\
\text { ber of } \\
\text { Indi- } \\
\text { viduals }\end{array}$ & $\begin{array}{c}\text { Num- } \\
\text { ber of } \\
\text { haplo- } \\
\text { types }\end{array}$ & $\begin{array}{c}\text { Haplotype } \\
\text { diversity }\end{array}$ & $\begin{array}{c}\text { Nucleotide } \\
\text { diversity }\end{array}$ & $\begin{array}{c}\text { Number } \\
\text { of poly- } \\
\text { morphic } \\
\text { sites }\end{array}$ & $\begin{array}{c}\text { Tajima D } \\
\text { test }\end{array}$ & $\begin{array}{c}\text { Fu's Fs } \\
\text { test }\end{array}$ \\
\hline Haplogroup A & 88 & 69 & $0.985 \pm 0.007$ & $0.02835 \pm 0.00987$ & 251 & -2.61426 & -51.021 \\
\hline Haplogroup B & 10 & 5 & $0.576 \pm 0.163$ & $0.00236 \pm 0.00084$ & 6 & -1.63248 & -1.578 \\
\hline Haplogroup C & 2 & 2 & $1.000 \pm 0.254$ & $0.01568 \pm 0.00723$ & 3 & $* * * *$ & 0.000 \\
\hline Haplogroup D & 3 & 3 & $1.000 \pm 0.272$ & $0.01802 \pm 0.00730$ & 13 & $* * * *$ & 0.987 \\
\hline Total & 105 & 81 & $0.984 \pm 0.006$ & $0.03953 \pm 0.00843$ & 273 & & \\
\hline
\end{tabular}

**** Four or more sequences are needed to compute Tajima D test 


\section{Haplogroup distribution}

Haplogroup distributions are presented in Figure 3. No haplogroup specific distribution patterns were found in Pakistani goat breeds or among the different ecological zones. The Beetal and Teddy goat breeds were more diversified with three haplogroups (A, B, D and A, B, C, respectively). Haplogroup A was most common in Pakistani goats across all zones examined in this study. The Nachi and Long Hairy breeds contained two Haplogroups A and B, $A$ and $C$ were found in Pateri, while $\mathrm{A}$ and D were found in Taprie breed. Figure 3 revealed that haplogroup A and $B$ were distributed in all ecological zones except the western areas, where only haplogroup A was observed.

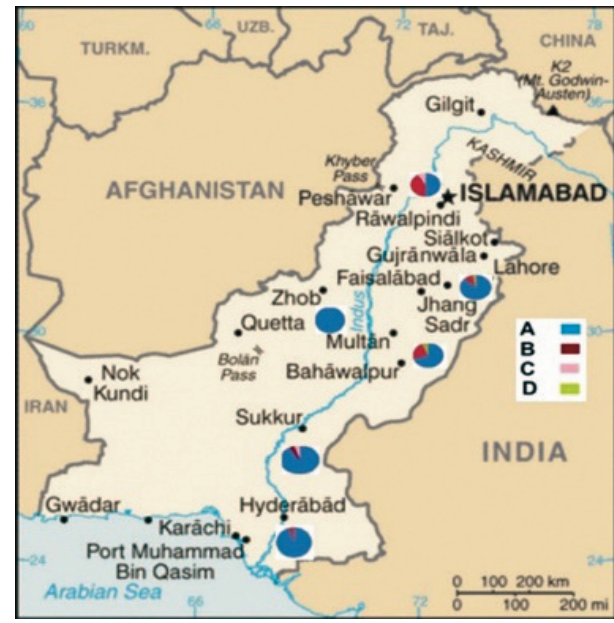

Figure 3. Geographical zones of Pakistani domestic goat breeds and distribution of four known haplogroups $A, B, C$, and $D$ in 19 investigated goat breeds. Each haplogroup is represented by a different colour

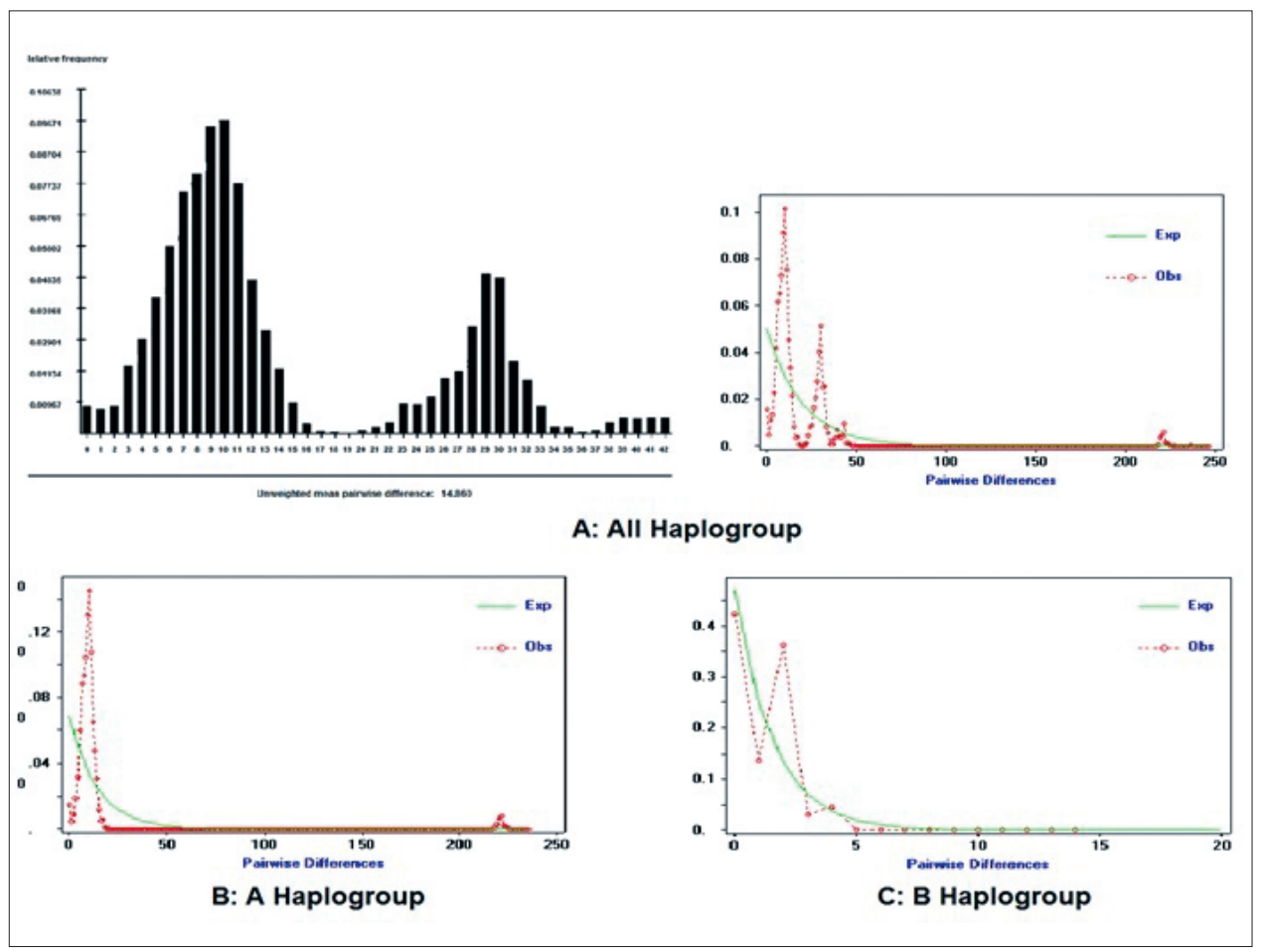

Figure 4. Mismatch distribution Al for the overall dataset, B) for the A haplogroup, C) for the B haplogroup. The $x$-axis represents the number of pairwise differences among sequences, and the $y$-axis represents the relative frequencies of pairwise comparisons 


\section{Population expansion}

The mismatch distribution for the complete dataset of all Pakistani goat breeds revealed two major peaks at positions 10 and 29, and very small peaks around 40 . The data showed that two expansion events in Pakistani goats occurred at about 10 and 29 mutational time units ago. Consequently, both neutrality tests Fu's Fs $(-43.933, P<0.01)$, and Tajima D test $(-2.28780, P<0.01)$ showed a significant departure from the neutrality assumption. We further performed mismatch distribution analysis for the predominant lineage A and moderate lineage B in Pakistani goat breeds. The evolutionary story for lineage $\mathrm{A}$ is of interest. Figure 4 reveals that lineage A underwent population expansion events, as detected by significantly large negative Fu's Fs value $(-51.021, P<0.01)$ and Tajima $D$ test $(-2.61426, P<0.01)$.

\section{Microsatellite marker analysis}

The descriptive statistics of the 11 microsatellites used for the genetic structure of Rajanpuri goas are presented in Supplementary Table 1. A total of 40 alleles were detected in the 11 microsatellite markers. The OarAE101 locus had the highest number of alleles (6), while the loci BM1818, ETH152 and OarVH72 had the lowest number of alleles (2) (Table 3). MAF70, OarFCB48, and OarAE101 had high allelic diversity with more than 5 alleles per locus, while the remaining loci had low allelic diversity. The average observed heterozygosity $\left(\mathrm{H}_{\mathrm{O}}\right)$ among the loci was $0.8342 \pm 0.1014$, ranging from 0.6450 (OarVH72) to 1.0000 (OarFCB48). The mean expected heterozygosity was $0.6480 \pm 0.1164$, while Nei's average heterozygosity was $0.6318 \pm 0.1135$ (Table $3)$. In the data analysis, the following loci OarVH72, BM1818, ILSTS011,

Table 3. Summary of the number of observed and expected alleles, observed and expected heterozygosity, Shannon index, Nei and F statistics and polymorphic information content (PIC) for all studied loci in Rajanpuri goat

\begin{tabular}{|l|c|c|c|c|c|c|c|c|}
\hline Locus & na* & ne* & I* & Obs_Het & Exp_Het* & Nei** & Fis & PIC \\
\hline MAF70 & 5 & 3.7209 & 1.4426 & 0.9570 & 0.7500 & 0.7312 & -0.3675 & 0.66 \\
\hline OarAE101 & 6 & 5.2632 & 1.7182 & 0.7000 & 0.8308 & 0.8100 & 0.1358 & 0.75 \\
\hline MAF33 & 4 & 3.2000 & 1.2555 & 0.9520 & 0.7051 & 0.6875 & -0.4545 & 0.58 \\
\hline OarVH72 & 2 & 2.0000 & 0.6931 & 0.6450 & 0.5128 & 0.5000 & -1.0000 & 0.28 \\
\hline BM1818 & 2 & 2.0000 & 0.6931 & 0.6550 & 0.5128 & 0.5000 & -1.0000 & 0.34 \\
\hline ILSTS011 & 3 & 2.7397 & 1.0487 & 0.9000 & 0.6513 & 0.6350 & -0.4173 & 0.47 \\
\hline MM12 & 3 & 2.5890 & 1.0169 & 0.8990 & 0.6295 & 0.6138 & -0.6293 & 0.42 \\
\hline ETH152 & 2 & 2.0000 & 0.6931 & 0.6790 & 0.5128 & 0.5000 & -1.0000 & 0.35 \\
\hline OarFCB48 & 5 & 3.4335 & 1.3462 & 1.0000 & 0.7269 & 0.7087 & -0.4109 & 0.68 \\
\hline BM1314 & 4 & 2.6578 & 0.9876 & 0.9600 & 0.9800 & 0.7500 & 0.1345 & 0.58 \\
\hline INRA032 & 4 & 3.1245 & 0.9888 & 0.8300 & 0.9500 & 0.6500 & 0.1298 & 0.59 \\
\hline Mean & 3.6363 & 2.9940 & 1.1008 & 0.8342 & 0.6480 & 0.6318 & -0.5124 & 0.52 \\
\hline St. Dev & 1.5092 & 1.0669 & 0.3692 & 0.1014 & 0.1164 & 0.1135 & - & \\
\hline
\end{tabular}

* na $=$ Observed number of alleles

* ne $=$ Effective number of alleles [Kimura and Crow (1964)]

* I = Shannon's Information index [Lewontin (1972)]

* Expected homozygosity and heterozygosity were computed using Levene, (1949)

** Nei's (1973) expected heterozygosity 
MM12, and ETH152 had a low level of polymorphic information content $(\mathrm{PIC}<0.40)$, though the remaining loci revealed a high level of informativeness (PIC $>0.5$ ) with an average of 0.52 . To determine whether the Rajanpuri goat population was in mutation-drift equilibrium, Bottleneck v1.2.02 software (Piry et al., 1999) was utilized. Three tests: sign test, standardized test (Cornuet and Luikart, 1996) and Wilcoxon signrank test (Luikart et al., 1998), were performed to fulfil the intention. Three different mutation models, i.e. IAMInfinite allele model, TPM-Two phase mutation model, and SMM-Strict one step mutation model, were applied to compile the analysis.

In the current study, we also estimated the genetic diversity in Rajanpuri goats using 11 microsatellite markers. The microsatellite markers with their chromosome number, type of repeats, total number of alleles, heterozygosity and polymorphic information content (PIC), are described in Tables 1 and 3. Among the polymorphic markers, the OarAE101 locus revealed the highest number of alleles (6) in the analysed population. Only two other markers (MAF70 and OarFCB48) had 5 alleles per locus, while the remaining markers showed less polymorphism. A total of 40 alleles was detected in the 11 microsatellite loci in the studied goat population. Allelic richness ranged from 2 (BM1818, ETH152, OarVH72) to 6 (OarAE101) across all microsatellite markers (Table 3).

\section{Discussion}

This study was conducted to determine the genetic diversity of a local goat breed from the southwestern part of Punjab province, famous due to its white body colour, using complete mtDNA control region and 11 microsatellite markers. The objective of this study was to analyse Rajanpuri goat genetic diversity, compared to about 18 species of native goats using D-mtDNA ring variation. Pakistan is a region of interest for the study of genetic diversity in goats. Archaeological evidence indicates that goats were the second species to be domesticated at the Mehrgarh site in Balochistan, Pakistan (Meadow, 1996), although the issues related to the origin of domestic goats remain debated.

In this study, region was identified by a preliminary analysis of the largest mitochondrial DNA variation, molecular similarity, and kinship between ethnic Pakistani goats. The high probability tree based on the 481 base pair mitochondrial DNA control region of the display was divided into four different Pakistan goat haplogroups $(\mathrm{A}, \mathrm{Bl}, \mathrm{C}$, and $\mathrm{D})$ based on the mtDNA control region. Though there are no Pakistan goat sequences from haplogroups $G$ and F, they usually occur in North Africa, the Middle East and Sicily (Naderi et al., 2007). Mitochondrial system A is most common, occurring in all ethnic groups and geographically distributed across the country. Previous studies have also identified its widest global distribution (Mannen et al., 2001; Mazdarani et al., 2014). Haplogroup B was divided into two sub-groups B1 and B2 in China. (Chen et al., 2005). The C and $\mathrm{D}$ lines were found in low frequencies in Pakistani goats (Naderi et al., 2007). Our findings support the theory of multiple maternal origins in domestic goats.

Analysis of the D-loop region
of mitochondrial DNA clearly demonstrated that the haplotypes of the Rajanpuri Beetal Pakistan strain goats formed two clades with high posterior probability (1.000) and high initial support (96\%). Phylogenetic analysis of the mitochondrial sequence of cytochrome $b$ also showed similar images with an estimated divergence time of $1.26 \pm 0.36$ million years. This 
study showed that Pakistan Beetal goats in Rajanpuri include many tribal samples, which was not previously reported.

In this study, there were no obvious geographical patterns in the goat population in Pakistan, indicating an excess of gene flow between local goat populations in the region due to frequent translocation. The weak results of the geographical structure of Pakistan goat is similar to reports from previous studies (Liu et al., 2007). MtDNA haplotypes in the haplogroup a network of the decentralized distribution network are not grouped individuals of the same geographic origin, providing evidence of a close phylogenetic relationship within Pakistan and high gene flow with domestic goat breeds. This type of model is consistent with the relationship in Ann Tory goats in Asia (Akis et al., 2014). As a result, some races from different geographic regions, grouped in similar haplogroups, share the same gene flow. Phylogenetic and network analysis showed that two races, Teddy and Nachi, had similar haplotypes in haplogroup B despite being from different geographic regions. Although the geography of the Pakistani mountains, forests and deserts represent relatively solitary, longestablished oases, gene flow may occur in and on the Silk Road among goats.

For all loci, allelic diversity is more conducive to analysis of possible genetic erosion in the population than heterozygosity (Mahmoudi et al., 2014). The average number of alleles (MNA) observed for each locus in Rajanpuri goats was 3.6. This value is greater than reported by Hussain et al. (2013). Among recent Pakistani goat breeds, and among other Pakistani goat breeds surveyed, Nachi (Baber et al. 2013; Hussain et al. 2013); Teddy (5.92) and Pahari (6.08) (Vahidi et al., 2014). However, the average number of alleles observed in this survey was lower than in other Chinese, Indian and Iranian goat breeds. The number of low alleles detected here indicates the presence of moderate polymorphisms. The highest polymorphism was detected in the locus OarFCB48 (1.0000), while the lowest in OarVH72 (0.6450). The mean heterozygosity observed and expected at all loci were 0.8342 and 0.6480, respectively. The average heterozygosity observed in Rajanpuri goats (0.8342) was higher than in other Damani (0.730), Nachi (0.510), Teddy (0.655) and Pahari (0.612) goats.

Of the 11 loci, 8 loci showed negative inbreeding coefficient $\left(\mathrm{F}_{\mathrm{IS}}\right)$ values, indicating an excess of heterozygotes (outbreeding), while 3 loci (OarAE101, BM1314, INRA032) revealed positive $\mathrm{F}_{\text {IS }}$ values in Rajanpuri goat, indicating an excess of homozygotes (inbreeding). The overall $F_{\text {IS }}$ values per locus showed more negative values than positive, representing many heterozygotes in the Rajanpuri goat population. Most loci showed a high degree of polymorphism, except the loci OarVH72, BM1818, ILSTS011, MM12, and ETH152 which had low PIC values (PIC $<0.40$ ), while the remaining loci revealed high level of in formativeness (PIC $>0.5$ ) with an average of 0.52 . Markers with PIC values of $<0.25$ are less informative. The markers were slightly less informative in Rajanpuri goat, with a mean of PIC 0.52 as compared to a mean PIC of 0.70 in other Pakistani goat breeds of Damani and Nachi.

\section{Conclusions}

In conclusion, analysis of mitochondrial DNA D-Loop of Rajanpuri strain of the Beetal goat breed of Pakistan revealed wide variations in the number and pattern of tandem repeats as compared to another Mouflon-form wild goat. This study is one of the first detailed analyses of microsatellite diversity in the mitochondrial control region fragments of other goat breeds in Pakistan and the 
Rajanpuri goat population. These results provide valuable information for understanding the genetic structure of this important local goat population for future genetic improvement and as a guide to establishing conservation plans in isolated areas. The findings also provide information that will help us establish a selection programme to protect genetic diversity and/or reduce excessive blood dependence in the population.

\section{Acknowledgements}

The authors thank all the technical personnel for their support and assistance in sample collection.

\section{References}

1. AHMED, Z., M. E. BABAR, T. HUSSAIN, A. NADEEM, F. L. AWAN, A. WAJID and S. A. SHAH ALI (2014): Genetic Diversity Analysis of Kail Sheep by Using Microsatellite Markers. J. Anim. Plant. Sci. 24, 1329-1333.

2. AKIS, I., K. OZTABAK and A. MENGI (2014): Mitochondrial DNA diversity of Anatolian indigenous domestic Goats. J. Anim. Breed. Genet. 131, 487-495.

3. BABAR, M. E., T. HUSSAIN, H. SADIA, A. NADEEM, M. Z. KAMRAN and N. BADSHAH (2014): Mitochondrial cytochrome b gene-based phylogeny of lohi and Thalli sheep breeds of Pakistan. J. Ani. Plant. Sci. 24, 1260-1262.

4. BANDELT, H. J., P. FORSTER and A. ROUHL (1999): Median-joining networks for inferring intraspecific phylogenies. Mol. Biol. Evol. 16, 37-48.

5. CANON, J., D. GARCIA, M. A. GARCIA-ATANCE, G. OBEXER-RUFF and J. A. LENSTRA (2006): Geographical partitioning of goat diversity in Europe and the Middle East. Anim. Genet. 37, 327334.

6. CHEN, S. Y., Y. H. SHA and Y. P. ZHANG (2005): Mitochondrial diversity and phylogeographic structure of Chinese domestic goats. Mol. Phylogenet. Evol. 37, 804-814.

7. CORNUET, J. M. and G. LUIKART (1996): Description and power analysis of two tests for detecting recent population bottlenecks from allele frequency data. Genet. 144, 2001-2014.

8. FU, Y. X. (1997): Statistical tests of neutrality of mutations against population growth, hitchhiking and background selection. Genet. 147, 915-925.

9. GLOWATZKI-MULLIS, M. L., J. MUNTWYLER, E. BA“UMLE and C. GAILLARD (2009): Genetic diversity of Swiss sheep breeds in the focus of conservation research. J. Anim. Breed. Genet. 126, 164-175.
10. GLOWATZKI-MULLIS, M. L., J. MUNTWYLER, E. BAUMLE and C. GAILLARD (2008): Genetic diversity measures of Swiss goat breeds as decision making support for conservation policy. Small. Rumin. Res. 74, 202-211.

11. HALL, T. A. (1999): BioEdit: a user-friendly biological sequence alignment editor and analysis program for Windows 95/98/NT. Nucl. Acids. 41, 95-98.

12. HAN, L., H. X. YU, D. W. CAI, H. L. SHI, H. ZHU and H. ZHOU (2010): Mitochondrial DNA analysis provides new insight into the origins of Chinese domestic goat. Small. Rumin. Res. 90, 41-46.

13. HUSSAIN, T., M. E. BABAR, H. SADIA, S. MISBAH, N. ASIF, A. AKHTAR, A. WAJID and S. A. SHAH (2013): Microsatellite markers based genetic diversity analysis in Damani and Nachi goat breeds of Pakistan. Pak. Vet. J. 33, 520-522.

14. LI, M. H., S. H. ZHAO, C. BIAN, H. S. WANG and H. WEI (2002): Genetic relationships among twelve Chinese indigenous goat populations based on microsatellite analysis. Genet. Sel. Evol. 34, 729-744.

15. LIBRADO, P. and J. ROZAS (2009): DNA SP. v5: software for comprehensive analysis of DNA polymorphism data. Bioinform. 25, 1451-1452.

16. LIU, R. Y., C. Z. LEI, S. H. LIU and G. S. YANG (2007): Genetic Diversity and Origin of Chinese Domestic Goats Revealed by Complete mtDNA D-loop Sequence Variation. Asian-Aust. J. Anim. Sci. 20, 178-183.

17. LUIKART, G., L. GIELLY, L. EXCOFFIER, J. D. VIGNE and J. BOUVET (2001): Multiple maternal origins and weak phylogeographic structure in domestic goats. Proc. Natl. Acad. Sci. 98, 5927-5932.

18. LUIKART, G. L., F. W. ALLENDORF, J. M CORNUET and W. B. SHERWIN (1998): Distortion of allele frequency distributions provides a test for recent population bottlenecks. J. Hered. 89, 238-247.

19. MAHMOUDI, B., B. PANAHI, S. A. MOHAMMADI, M. DALIRI and M. S. BABAYEV (2014): Microsatellite based phylogeny and bottleneck studies of Iranian indigenous goat populations. Animal. Biotech. 25, 210-222.

20. MANNEN, H., Y. NAGATA and S. TSUJI (2001): Mitochondrial DNA reveal that domestic goat (Capra hircus) is genetically averted by two subspecies of bezoar (Capra aegagurus). Biochem. Genet. 39, 145-154.

21. MAZDARANI, F. H., M. T. AKBARI, R. M. FARD, M. HESSARI and K. C. POUR (2014): Molecular identification of Capra hircus in East Chia Sabz, an Iranian pre-pottery neolithic site, central Zagros, based on MtDNA. J. Anim. Plant. Sci. 24, 945-950.

22. MEADOW, R. H. (1996): The Origins and Spread of Agriculture and Pastoralism in Eurasia, ed. Harris, D. R. (Smithsonian Inst., Washington, DC), pp. 390-412.

23. NADERI, S., H. R. REZAEI, P. TABERLET, S. ZUNDEL and S. A RAFAT (2007): Large-scale mitochondrial DNA analysis of the domestic goat reveals six haplogroups with high diversity. PLoS. One. 2, e1012. 
24. PIRY, S., G. LUIKART and J. M. CORNUET (1999): BOTTLENECK: A program for detecting recent effective population size reductions from allele frequency data. J. Hered. 90, 502-503.

25. PRINGLE, H. (1998): Reading the signs of ancient animal domestication. Science 282, 1448-1448.

26. ROGERS, A. R. and H. HARPENDING (1992): Population growth makes waves in the distribution of pairwise genetic differences. Mol. Biol. Evol. 9, 552-569.

27. SULTANA, S., H. MANNEN and S. TSUJI (2003): Mitochondrial DNA diversity of Pakistani goats. Anim. Genet. 34, 417-421.

28. TAMURA, K., G. STECHER, D. PETERSON, A. FILIPSKI and S. KUMAR (2013): MEGA6: Molecular Evolutionary Genetics Analysis Version 6.0. Mol. Biol. Evol. 30, 2725-2729.
29. VAHIDI, S. M. F., A. R. TARANG, N. ARIF-UNNISA, F. A. MOHSEN, P. BOETTCHER, S. JOOST, L. COLLI, J. F. GARCIA and P. AJMONE-MARSAN (2014): Investigation of the genetic diversity of domestic Capra hircus breeds reared within an early goat domestication area in Iran. Genet. Select. Evol. 46, 27-32.

30. WAJID, A., T. HUSSAIN, M. WASIM, M. E. BABAR, A. A. ANJUM, S. A. SHAH, K. ABBAS, M. M. MANZOOR and N. BADSHAH (2013): The future prospective of genomic biotechnology in animal Breeding: their potential for livestock production in Pakistan. J. Anim. Plant. Sci. 23, 944-955.

31. YEH, F. C. and R. YONG (2015): POPGENE version 1.31: Microsoft-based Freeware for Population Genetic Analysis. University of Alberta, Edmonton, Canada.

\section{Molekularna istraživanja na rajanpuri soju pasmine beetal koza iz Pakistana potpunim područjem pomaka mtDNK i mikrosatelitnim markerima}

Dr. sc. Abdul WAJID, dr. med. vet., dr. sc. Tanveer HUSSAIN, dr. med. vet., redoviti profesor, dr. sc. Kamran ABBAS, dr. med. vet., dr. sc. Akhtar ALI, dr. med. vet., dr. sc. Masroor Ellahi BABAR, dr. med. vet., redoviti profesor, dr. sc. Masroor ELLAHI BABAR, dr. med. vet., redoviti profesor, Zavod za molekularnu biologiju, Univerzitet Virtual u Pakistanu, Lahore, Pakistan; dr. sc. Faiz M. M. T. MARIKAR, dr. med. vet., Univerzitet General Sir John Kotelawala Defense, Ratmalana, Šri Lanka; dr. sc. Muneeb M. MUSTHAFA, dr. med. vet., Zavod za biosistemsku tehnologiju, Tehnološki fakultet, Jugoistočni Univerzitet u Šri Lanki, Univerzitetski park, Oluvil, Šri Lanka

Mitohondrijske DNK sekvence DNK-D petlji (mtDNK) 105 jedinki (11 ratalpuri sojeva beetal koze i 94 sekvence iz GenBank) od 19 geografskih i fenotipičnih domaćih pasmina koza u Pakistanu rabljeno je u ovom eksperimentu. U ovoj smo studiji istražili varijabilnost i njezinu molekularnu filogeniju. Zamijećen je ukupno 81 različit haplotip u 105 jedinki s raznolikošću haplotipova $0,984 \pm 0,006$ i nukleotidnom raznolikošću $0,03953 \pm 0,00843$. Filogenetskom analizom ustvrđen iz mtDNK hipervarijabilni segment (HVI) kontrolnog područja (481 bp) i pokazala je četiri haploskupine mtDNK (A, B1, C i D) identificirane u pakistanskih domaćih koza, u kojima se haploskupina A $(84,11 \%)$ pokazala dominantnom i široko rasprostranjenom među svim istraživanim pasminama. Studija je otkrila da svi haplotipovi rajanpuri soja pripadaju haploskupini A. Rajanpuri je rijedak lokalni soj beetal pasmine koza smješten u zapadnoj regiji provincije Punjab u Pakistanu. Rezultati genetske raznolikosti na temelju 11 mikrosatelitnih lokusa otkrili su alelnu raznolikost $(3,6363)$ i visoku genetsku raznolikost $(0,8342)$ istraživane rajanpuri pasmine koza. Rezultati analize za potpis za događaje uskog grla uporabom tri modela otkrili su značajno odstupanje rajanpuri koza od ravnoteže mutacija i pomaka. Kvalitativni test analize modalnog pomaka podržao je i rezultate dobivene trima modelima, ukazujući na prisutnost genetskog uskog grla u rajanpuri soja u nedavnoj prošlosti. Ova studija po prvi put pruža informacije o arhitekturi mtDNK, genetskoj raznolikosti, analizi uskog grla koje će biti korisne u donošenju odluke o očuvanju i upravljanju cijenjenom i skupocjenom rajanpuri kozom.

Ključne riječi: $m t D N K$ D-petlja, filogenetska analiza, mikrosatelitni marker, analiza uskog grla, rajanpuri koza, Pakistan 